\title{
PRODUCTION OF 'CORTIBEL' GROUP GUAVA SEEDLINGS ON DIFFERENT SUBSTRATES
}

Vanessa Brenda Souza Chaves ${ }^{1}$, Francielly Rodrigues Gomes ${ }^{1, *}$, Moab Acácio Barbosa ${ }^{1}$, Lasara Kamila Ferreira de Souza ${ }^{1}$, Ana Laura Pereira Souza ${ }^{1}$, Laísse Danielle Pereira ${ }^{2}$, Marcelo Marques Costa ${ }^{1}$, Danielle Fabíola Pereira da Silva ${ }^{1}$, Américo Nunes da Silveira Neto ${ }^{1}$

\begin{abstract}
The guava (Psidium guajava L., Myrtaceae) is originates of Tropical America and is distributed throughout the Brazilian territory. The seedling production stage is very important because seedlings of higher quality have a direct influence on success and final production. Therefore, it is necessary to use substrates with good nutritional quality to supply the nutrient demand of the crop. In this way, the objective of this study was to evaluate the germination of 'Cortibel' guava seeds and initial development of the plants in different substrates. The seeds were obtained in physiologically mature fruits and sown in $1.5 \mathrm{~L}$ bags with two types of substrate (sand and commercial substrate Bioplant ${ }^{\circledR}$ ). The design was completely randomized, two substrates were the treatments with nine replicates and each repetition with five bags, totaling 45 experimental units for each treatment. Germination was monitored for 129 days. The characteristics of plant height, stem diameter and number of leaves were evaluated. The substrate sand provided a higher germination rate in relation to the Bioplant ${ }^{\circledR}$ substrate, however, the use of commercial substratum presented a higher initial development, with higher values of plant height and stem diameter, which is indicated for the production of seedlings of guava 'Cortibel' by seeds due to the presence of nutrients in its composition.
\end{abstract}

Keywords: germination, Psidium guajava L., seminiferous propagation.

\section{PRODUÇÃO DE MUDAS DE GOIABEIRA DO GRUPO 'CORTIBEL' EM DIFERENTES SUBSTRATOS}

\begin{abstract}
RESUMO - A goiabeira (Psidium guajava L., Myrtaceae) é originária da América Tropical e está distribuída em todo o território brasileiro. A fase de produção de mudas é muito importante, pois mudas de maior qualidade influenciam diretamente no sucesso e na produção final. Portanto, faz-se necessário o uso de substratos com boa qualidade nutricional para suprir a demanda de nutrientes da cultura. Dessa forma, o objetivo deste trabalho foi avaliar a germinação de sementes de goiaba 'Cortibel' e o desenvolvimento inicial das plantas em diferentes substratos. As sementes foram obtidas em frutos fisiologicamente maduros e semeadas em sacos de 1,5 L, com dois tipos de substrato (areia e substrato comercial Bioplant ${ }^{\circledR}$ ). O delineamento foi inteiramente casualizado, onde os dois substratos foram os tratamentos com nove repetições e cada repetição com cinco sacos, totalizando 45 unidades experimentais para cada tratamento. A germinação foi monitorada por 129 dias. Foram avaliadas as características: altura das plantas, diâmetro do caule e número de folhas. O substrato areia proporcionou maior taxa de germinação em relação ao substrato Bioplant ${ }^{\circledR}$, porém, o uso de substrato comercial apresentou maior desenvolvimento inicial, com maiores valores de altura de planta e diâmetro de caule, o que é indicado para a produção de mudas de goiaba 'Cortibel' por sementes devido à presença de nutrientes em sua composição.
\end{abstract}

Palavras chave: germinação, propagação seminífera, Psidium guajava L.

\footnotetext{
${ }^{1}$ Universidade Federal de Goiás - Regional Jataí, Br 364, km 192, 75801-615. Jataí - Goiás - Brazil.

${ }^{2}$ Instituto Federal Goiano - Campus Rio Verde, Rodovia Sul Goiana, Km 01, Zona Rural, 75.901-970. Rio Verde - Goiás - Brazil.

* Corresponding author: Francielly Rodrigues Gomes, mestranda do programa de pós-graduação em agronomia, Universidade Federal de Goiás - Regional Jataí, Bolsista da CAPES, E-mail: fram_rodgomes@hotmail.com
} 


\section{INTRODUCTION}

The guava (Psidium guajava L., Myrtaceae) is native of tropical America, being distributed throughout Brazilian territory (Souza et al., 2017). It is a culture of great socioeconomic importance for some regions, due to its rusticity and great acceptance in the market, and its consumption can be as much in natura as in the form of sweets, juices, jellies and other processed products. The fruit has high nutritive value, rich in iron, calcium, phosphorus, vitamin $\mathrm{A}$ and $\mathrm{B}$ complex, besides high levels of vitamin $\mathrm{C}$ (ascorbic acid), higher levels than those found in orange (Campos et al., 2013).

The propagation of guava can be done both sexually and asexually, with the most commonly used techniques being by cutting and air layering. The use of seeds for seedlings production is uncommon and the production of rootstocks and genetic breeding is often restricted (Hossel et al., 2016). However, Altoé et al. (2011) reported a low percentage of rooting for varieties of the Cortibel group when stakes were used, these values would be around 5 to $8 \%$ for herbaceous cuttings regardless of the dosage of indolebutyric acid used, which justifies the use of seeds of this group in scientific studies.

The seedlings production phase is one of the most important in the production process, with the best quality seedlings, vigorous and free of pests and diseases, directly influencing the success and final production of the crop. These characteristics are strongly influenced by the type and quality of the substrate used in seedling production (Diniz et al., 2015).

A good substrate must have porosity and adequate water retention capacity for satisfactory development of the seedlings. In addition, it must be free of pests, pathogens and invasive plant seeds, which compromise the health and quality of seedlings (Souza et al., 2016). Also, good nutritional quality of the substrates, which meet the requirements of the culture, is indispensable (Diniz et al., 2015).

Seeds may present variable responses on different substrates, and it is advisable to study the influence of this component on germination (Hossel et al., 2017). According to Marques et al. (2018), the substrate has a fundamental role in the germination of seeds and with the existence of many types in the market, it is necessary to verify the best substrate that provides the formation of seedlings of better quality of the species of interest (Nogueira et al., 2014)

Therefore, the objective of this study was to evaluate seed germination and the initial development of 'Cortibel' guava seedlings on different substrates in Jataí, GO, Brazil.

\section{MATERIALAND METHODS}

The experiment was conducted at the Federal University of Goiás - Jataí Regional, in experimental nursery, located at latitude $17^{\circ} 55^{\prime}$ south and longitude $51^{\circ} 43^{\prime}$ west. According to the classification of Köppen, the climate of the region is Aw type, with the dry season defined from May to September, and the rainy season, from October to April. The average temperature is $23.3^{\circ} \mathrm{C}$.

Fruits of the cultivar 'Cortibel' (Australian variety $\mathrm{x}$ Brazilian variety) were harvested completely mature and transported to the laboratory, where they were selected for the absence of diseases and mechanical damages, washed and dried at room temperature. Afterwards, they were cut in half and the seeds were removed and subjected to removal of the pulp with running water and lime. After that, the seeds were washed in running water with polyethylene sieves.

After the seeds were removed, five seeds were placed in each bag at $1.0 \mathrm{~cm}$ depth. Nine bags per treatment were used, with a capacity of $1.5 \mathrm{~L}$ each, containing medium textured sand or commercial Bioplant ${ }^{\mathbb{B}}$ substrate. The germination occurred 129 days after sowing (DAS), when only one plant was left per bag, preferring the more vigorous.

The Bioplant ${ }^{\circledR}$ commercial substrate consists of coconut fiber, pinus bark, manure, sawdust, vermiculite, rice husk, ash, agricultural gypsum, calcium carbonate, magnesium, magnesium thermophosphate (yoorin) and additives (fertilizers).

The experimental design was a completely randomized (DIC) with two treatments (sand substrate and Bioplant substrate) and nine replicates, each replicate was formed by five bags totaling 45 experimental units for each treatment.

Germination was monitored throughout the experimental period through visual evaluations of seedling emergence. 
After 129 days it was evaluated: height of the plants with the aid of graduated ruler, the diameter of the stem with digital caliper and number of leaves.

Data were submitted to analysis of variance and the means of the analyzed variables were compared by the $\mathrm{F}$ test, at the $5 \%$ probability level. The characteristics of the seedlings were correlated by the Pearson correlation, at $1 \%$ probability. The data were analyzed in the statistical software SAS (Statistical Analysis System, 2002).

\section{RESULTS AND DISCUSSION}

The results obtained regarding germination, plant height, stem diameter and number of leaves were influenced by the type of substrate used (Table 1). Seeds grown on the sand substrate had $93.33 \%$ germination, which can be explained due to the porosity provided by the substrate. Much lower results were found by Navroski et al. (2017), evaluating the influence of different substrates (Soil, carbonized rice husk + soil + sand, charred rice husk + sand + crude rice husk and expanded vermiculite) about the emergency and initial establishment of guava - cv. Serrana seedlings under greenhouse conditions, where germination averages ranging from 65.25 to $83.5 \%$ were observed.

According to Fantinel et al. (2015), germination percentages greater than $61 \%$ represent a positive characteristic for seedlings produced through sexual propagation. This assertion demonstrates the potential of the cultivar under study to be seed propagated using sand as substrate. In the germination process, the substrate has a considerable influence, and may cause restrictions in the development of the plants, since it serves as initial support (Bortolini et al., 2017). Substrates with adequate porosity allow the movement of water and gas exchange, which favors germination, providing good conditions to the seed to express their maximum vigor and germination potential (Costa et al., 2017).
The data of germination in sand corroborate with Gomes et al. (2016) in a study carried out with different substrates for the germination test in seeds of Myrtaceae species, where they observed good germination conditions, around $82 \%$, for the Eugenia pyriformis species germinated in this type of substrate.

Silva et al. (2016) evaluated the temperature and the substrates in germination of Plukenetia volubilis L. seeds grown in plastic boxes under nursery conditions in Manaus-AM, obtained the lowest germination values for the commercial substrates Basaplant ${ }^{\mathbb{B}}$ and Bioplant ${ }^{\mathbb{B}}$, similar pattern to that observed in the germination of guava trees in the present study, where $48.89 \%$ emerged. This can be explained by a probable accumulation of moisture that prevented the maximum germination of the seeds cultivated in this substrate. It was verified that the use of the Bioplant ${ }^{\circledR}$ substrate did not favor the germination of guava seeds, even though it contained several materials in its composition. This is probably due to the high-water retention capacity, together with deficient aeration in the substrate, as the triggering of the germ process of a viable seed requires adequate environmental conditions of humidity, temperature, oxygen and, in some cases, light (Cosmo et al., 2017).

Some authors reported difficulties in the germination of forest species when cultivated in Bioplant ${ }^{\mathbb{}}$, in which the commercial substrate did not provide good growth conditions in Eugenia calycina (Borges et al., 2016) and Copaifera langsdorffii (Dutra et al., 2012).

The plant height variable differed statistically among the treatments evaluated, but higher performance was observed in seedlings grown on the Bioplant ${ }^{\mathbb{B}}$ substrate, with a mean of $12.89 \mathrm{~cm}$. The greater development may be conditioned to the nutrients present in its composition, thus favoring the metabolism of the plant which, in turn, presents low nutritional requirements (Diniz et al., 2015).

According to Moreira et al. (2015) and Afonso et al. (2017) the sand substrate is inert, contains no

Table 1 - Plant height $(\mathrm{cm})$, stem diameter $(\mathrm{mm})$, number of leaves and percentage of germination of guava seedlings on two substrates

\begin{tabular}{lcccc}
\hline Treatment & Percentage germination (\%) & Plant height & Stem diameter & Number of leaves \\
\hline Sand & $93.33 *$ & $8.72 *$ & $0.49 *$ & $10.81 \mathrm{~ns}$ \\
Bioplant $^{\circledR}$ & $48.89 *$ & $12.89 *$ & $1.38 *$ & $11.04 \mathrm{~ns}$ \\
CV $(\%)$ & 14.09 & 10.29 & 12.68 & 10.47 \\
\hline
\end{tabular}

* Significant at the $5 \%$ probability level by the $\mathrm{F}$ test. Not significant at the $5 \%$ probability level by the $\mathrm{F}$ test. 
nutrients and has no colloidal properties, as verified in Bioplant ${ }^{\mathbb{B}}$. In this way, it would not promote greater increase of this characteristic. In order to determine the effect of the substrate on the plant characteristics, it is necessary to study the substrate effect to obtain better quality seedlings, since the great majority of the species are sexually propagated and the effect of the substrates on the characteristics of the plant vary (Silva et al., 2017).

It was verified that the seedlings grown on the Bioplant ${ }^{\circledR}$ substrate obtained a larger stem diameter, where a mean diameter of $1.08 \mathrm{~mm}$ was verified. According to Freitas et al. (2013) in a study of the production of seedlings grown on substrate with humic acid, it was verified that the Bioplant ${ }^{\circledR}$ substrate demonstrated efficiency in the development of guava plants. These authors also observed that the sand substrate, although being well used in the seed germination process, does not present colloidal or nutrient properties, and it is necessary to add other organic sources to obtain superior results in both germination and plant development.

The increase in stem diameter may be related to the availability of nutrients contained in the Bioplan $t^{\mathbb{R}}$ substrate, such as calcium carbonate, magnesium, magnesium thermophosphate (yoorin) and additives (fertilizers), which in a balanced way has the capacity to promote greater production of plant biomass (Guerra et al., 2017).

The number of leaves was on average 11.04 in seedlings grown in Bioplant ${ }^{\circledR}$, which did not differ statistically from the sand substrate, although a higher average was verified for plants grown on the commercial substrate. Similar results were observed by Vendruscolo et al. (2017) that in a study with different volumes of casts and types of seeds in the production of Plinia cauliflora seedlings cultivated in the Bioplant ${ }^{\mathbb{B}}$ substrate obtained at 140 days after sowing the average between 8.22 and 12.90 leaves. These results are due to the probable content of calcium and magnesium present in the commercial substrate, which according to Andrade et al. (2013) stimulates the emission of new leaves and contributes to the growth of this organ.

A positive and significant correlation was observed between the number of leaves of height of plants, evidencing that as there was an increase in the size of the seedlings there was an increase in the number of leaves (Table 2). Positive correlation was also observed between the diameter and height of the seedlings, showing that the characteristics evaluated had directly proportional increments. The correlation intensity classification for $\mathrm{p}<0.01$ was considered to be very strong $(\mathrm{r} \pm 0.91$ to \pm 1.00$)$, strong $(\mathrm{r} \pm 0.71$ to \pm 0.90$)$, mean $(\mathrm{r} \pm 0.51$ to \pm 0.70$)$ and weak $(\mathrm{r} \pm 0.31$ to \pm 0.50$)$ (Guerra \& Liveira, 1999). Thus, there was a positive correlation of mean intensity between the diameters and seedling height characteristics; number of leaves and height of seedlings and weak correlation between diameter and number of leaves.

A positive and significant correlation was observed for all traits under study, except for the sand substrate with height and seedling diameter, that the interaction was positive and not significant. The correlation between the Bioplant ${ }^{\circledR}$ substrate and seedling height with leaf number was $0.836 * *$ which is considered a strong correlation, which shows that in these substrates these characteristics were better expressed (Table 3).

For Silva et al. (2013) the study of correlations between characteristics of agronomic interest is of great importance, since it provides subsidies to the breeder, since the selection efficiency can be increased with the use of correlated characteristics. In addition, obtaining genetic gains and classifying superior genotypes are, in many cases, obtained together (Borges et al., 2011).

Table 2 - Estimation of correlation coefficients between height $(\mathrm{H})$, diameter $(\mathrm{D})$ and leaf number $(\mathrm{LN})$

\begin{tabular}{cccc}
\hline Variables & $\mathrm{H}$ & $\mathrm{LN}$ & $\mathrm{D}$ \\
\hline $\mathrm{H}$ & 1.00 & & \\
$\mathrm{LN}$ & $0.58 * * 0.000$ & 1.00 & \\
$\mathrm{D}$ & $0.69 * 0.000$ & $0.41 * * 0.000$ & 1.00 \\
\hline
\end{tabular}

**: significant correlation at $1 \%$. Cell content: Pearson correlation, p-value.

Table 3 - Estimation of the correlation coefficients between the height $(\mathrm{HxLN})$, diameter (HXD) and leaf number $(\mathrm{LNxD})$ variables in the sand and Bioplant substrates

\begin{tabular}{llll}
\hline Substrates & H $\times$ NF & \multicolumn{1}{c}{ H x D } & \multicolumn{1}{c}{ NF x D } \\
\hline Sand & $0.457^{* *}$ & $0.243 \mathrm{~ns}$ & $0.533^{* *}$ \\
& 0.002 & 0.120 & 0.000 \\
Bioplant & $0.836^{* *}$ & $0.694^{* *}$ & $0.534^{* *}$ \\
& 0.000 & 0.000 & 0.008 \\
\hline
\end{tabular}

**: significant correlation at $1 \%$. ns: not significant. Cell content: Pearson correlation, p-value. 
In general, better germination rates were observed for seeds on sand substrates, on average above $90 \%$ germination. For the Bioplant substrate the germination percentage was close to $50 \%$, where it was observed a better initial development of the seedlings, being this one the most suitable for the production of 'Cortibel' guava seedlings via sexual propagation.

\section{CONCLUSIONS}

The substrate sand provides a higher germination rate, while the commercial substrate Bioplant ${ }^{\mathbb{E}}$ provides greater height and diameter measurements during the initial development of the guava seedlings.

\section{LITERATURE CITED}

AFONSO, M. V.; MARTINAZZO, E. G.; AUMONDE, T. Z. et al. Parâmetros fisiológicos de mudas de Albizia niopoides produzidas em diferentes composições de substrato. Ciência Florestal, v.27, n.4, p.1395-1402, 2017. http://dx.doi.org/10.5902/ 1980509830221 .

ALTOÉ, J. A.; MARINHO, C. S.; TERRA, M. D. C. et al. Multiplicação de cultivares de goiabeira por miniestaquia. Bragantia, v.70, n.4, p.801-809, 2011. http://dx.doi.org/10.1590/S0006-87052011000400011.

ALVES, C. Z.; SILVA, J. B.; CÂNDIDO, A. C. S. Metodologia para a condução do teste de germinação em sementes de goiaba. Revista Ciência Agronômica, v.46, n.3, p. 615-621, 2015. http:// dx.doi.org/10.5935/1806-6690.20150045.

ANDRADE, A. P.; BRITO, C. C.; SILVA JÚNIOR, J. et al. Estabelecimento inicial de plântulas de Myracrodruon urundeuva allemão em diferentes substratos. Revista Árvore, v.37, n.4, p.737-745, 2013. http://dx.doi.org/10.1590/S0100-67622013000400017.

BORGES, K. C. F.; SANTANA, D. G.; LOPES, S. W. et al. Coloração do fruto e substrato na emergência e no crescimento de plantas de Eugenia calycinas Cambess. Floresta e Ambiente, v.23, n.4, p.544-554, 2016. http://dx.doi.org/10.1590/2179-8087.144215.

BORGES, V.; SOBRINHO, F. S.; LÉDO, F. J. S.; KOPP, M. M. Associação entre caracteres e análise de trilha na seleção de progênies de meios irmãos de Brachiaria ruziziensis. Revista Ceres, v.58, p.65772, 2011. http://dx.doi.org/10.1590/S0034737X2011000600013.
BORTOLINI, J.; TESSARO, D.; GONÇALVES, M. $\mathrm{S}$. et al. Lodo de esgoto e cama de aviário como componente de substratos para a produção de mudas de Cedrela fissilis e Anadenanthera macrocarpa (benth). Brenan. Scientia Agraria, v.18, n.4, p.121-128, 2017.

CAMPOS, B. M.; VIANA, A. P.; QUINTAL, S. S. R. et al. Quantificação da divergência genética entre acessos de goiabeira por meio da estratégia Ward-MLM. Revista Brasileira de Fruticultura, v.35, n.2, p.571-578, 2013. http:// dx.doi.org/10.1590/S0100-29452013000200028.

COSTA, J. C. F.; FERNANDES, L. F.; OLIVEIRA, F. P. at al. Caracterização física de substratos orgânicos para o enraizamento de estacas de goiabeira. Brazilian Journal of Sustainable Agriculture, v.7, n.2, 2017. http://dx.doi.org/ 10.21206/rbas.v7i2.390.

COSMO, N. L.; GOGOSZ, A. M.; REGO, S. S. et al. Morfologia de fruto, semente e plântula, e germinação de sementes de Myrceugenia euosma (o. berg) d. legrand (Myrtaceae). Revista Floresta, v.47, n.4, p.479-488, 2017. http://dx.doi.org/ 10.5380/rf.v47i4.46933.

DINIZ, M. B. V. S; MESQUITA, E. F.; SÁ, F. V. S. et al. Crescimento de porta-enxertos de goiabeira influenciado por doses de biofertilizantes, tipo e volume de substrato. Científica, v.43, n.2, p.165178, 2015. http://dx.doi.org/10.15361/19845529.2015v43n2p165-178.

DUTRA, T. R.; GRAZZIOTTI, P. H.; SANTANA, R. C. et al. Desenvolvimento inicial de mudas de copaíba sob diferentes níveis de sombreamento e substratos. Revista Ciência Agronômica, v.43, n.2, p.321-329, 2012. http://dx.doi.org/10.5902/1980509821061

FANTINEL, V. S.; DE OLIVEIRA, L. M.; CASA, R. T. et al. Fungos associados às sementes de Acca sellowiana: efeitos na qualidade fisiológica das sementes e transmissão. Agrarian, v.10, n.38, p.328-335, 2017. https://doi.org/10.30612/ agrarian.v10i38.4509.

FREITAS, J. A. A.; MARINHO, C.S.; FREITAS, I.L.J. Goiabeiras Paluma, Pedro Sato e Cortibel propagadas por miniestaquia e miniestaquia seriada. Ciência Rural, v.43, n.8, p.1351-1356, 2013. http://dx.doi.org/10.1590/S010384782013000800002 . 
GUERRA, M. S.; BARBOSA, M. S.; COSTA, E. et al. Recipiente biodegradável e substratos para mudas de maracujazeiro. Revista de Agricultura Neotropical, v.4, n.3, p.50-54, 2017. https:// doi.org/10.32404/rean.v4i3.1641.

GUERRA, N.B.; LIVEIRA, A.V.S. Correlação entre o perfil sensorial e determinações físicas e químicas do abacaxi cv. Pérola. Revista Brasileira de Fruticultura, v.21, p.32-35, 1999.

GOMES, J. P.; OLIVEIRA, L. M.; FERREIRA, P. I. et al. Substratos e temperaturas para teste de germinação em sementes de Myrtaceae. Revista Ciência Florestal, v.26, n.4, p.285-293, 2016. dx.doi.org/10.5902/1980509821120.

\section{HOSSEL, J. S. A.O; HOSSEL, C.; WAGNER} JÚNIOR, A. et al. Estratificação, substrato e temperatura na germinação de sementes de araçazeiro vermelho. Brazilian Journal of Applied Technology for Agricultural Science, v.10, n.3, 2017. dx.doi.org/10.5935/PAeT.V10.N3.09.

HOSSEL, C.; HOSSEL, J.S.A.O.; WAGNER JÚNIOR, A. et al. Qualidade fisiológica de sementes de goiabeira branca de acordo com a extração e o armazenamento. Brazilian Journal of Applied Technology for Agricultural Science, v.9, n.3, p.61-68, 2016. dx.doi.org/10.5935/

PAeT.V9.N3.07.

MARQUES, A. R. F.; OLIVEIRA, V.S; BOLIGON, A. A. et al. Produção e qualidade de mudas de Psidium cattleianum var. cattleianum Sabine (Myrtaceae) em diferentes substratos. Acta Biológica Catarinense, v.5, n.1, 2018. dx.doi.org/ 10.21726/abc.v5i1.374.

MOREIRA, E.R.; BOLIANI, A.C.; CORRÊA, L.S. et al. Tratamentos pré-germinativos e substratos na emergência de sementes e qualidade de mudas de pinhão manso (Jatropha curcas L.). Semina: Ciências Agrárias, v.36, n.2, 2015. dx.doi.org/ 10.5433/1679-0359.2015v36n2p657.
NAVROSKI, R.; SILVA, P. S.; VALERON, C. et al. Germinação de sementes e estabelecimento de mudas de goiabeira-serrana e Araçá-pera em diferentes substratos. Revista Brasileira de Engenharia e Sustentabilidade, v.4, n.2, p.16-20, 2017. dx.doi.org/ 10.15210/rbes.v4i2.11943.

STATISTICAL ANALYSIS SYSTEM. SAS Institute Cary, N.C. EEUU. Version 9.0. 2002.

SILVA, R. B.; MATOS, V. P.; FARIAS, S. G. et al. O. Germinação e vigor de plântulas de Parkia platycephala Benth em diferentes substratos e temperaturas. Revista Ciência Agronômica, v.48, n.1, p.142, 2017. dx.doi.org/10.5935/1806-6690.20170016.

SILVA, D. F. P.; SILVA, J. OC.; MATIAS, R. G. P. et al. Correlação entre características quantitativas e qualitativas de frutos de pessegueiros na geração F2 cultivados em região subtropical. Revista Ceres, v.60, p.53-58, 2013. dx.doi.org/10.1590/S0034737X2013000100008.

SILVA, G.Z.; VIEIRA, V. A.; BONETI, J. E. et al. Temperature and substrate on Plukenetia volubilis $\mathrm{L}$. seed germination. Revista Brasileira de Engenharia Agrícola e Ambiental, v.20, n.11, p.1031-1035, 2016. dx.doi.org/10.1590/1807-1929/agriambi.v20n11p1031-1035 .

SOUZA, L. P.; NOBRE, R. G.; SILVA, E. M. et al. Produção de porta-enxerto de goiabeira cultivado com águas de diferentes salinidades e doses de nitrogênio. Revista Ciência Agronômica, v.48, n.4, p.596-604, 2017. dx.doi.org/10.5935/18066690.20170069 .

SOUZA, L.P.; NOBRE, R. G., SILVA, E. M.; LIMA, G. S. et al. Formation of 'Crioula' guava rootstock under saline water irrigation and nitrogen doses. Revista Brasileira de Engenharia Agrícola e Ambiental, v. 20, p.739-745, 2016. dx.doi.org/10.1590/1807-1929/ agriambi.v20n8p739-745.

VENDRUSCOLO, E. P.; CAMPOS, L. F. C.; SELEGUINI, A. Volume of containers and types of seeds for jabuticabeira seedling production. Scientia Agraria Paranaensis, v.16, n.4, p.485-489, 2017. dx.doi.org/10.18188/1983-1471/sap.v16n4p485-489.

Recebido para publicação em 18/12/2018 e aprovado em 27/03/2019. 